\title{
PENGARUH KINERJA KEUANGAN TERHADAP NILAI PERUSAHAAN YANG DIMEDIASI OLEH PENGUNGKAPAN SUSTAINABILITY REPORT
}

\author{
Susanti Widhiastuti ${ }^{(1)}$ \\ Eftianto $^{(2)}$ \\ Slamet Ahmadi ${ }^{(3)}$ \\ Prodi Manajemen \\ STIE IPWIJA \\ Santiwidhiatuti@gmail.com ${ }^{(1)}$ \\ eftianto@gmail.com ${ }^{(2)}$ \\ Slametahmadi10@gmail.com ${ }^{(3)}$
}

\begin{abstract}
This study aims to determine the effect of financial performance, on the value of the company with disclosure of sustainability report as a mediating variable. The population in this study are companies listed on the Indonesia Stock Exchange and consistently included in the SRIKEHATI Index from 2012-2016 as many as 19 companies. The selection of samples using purposive sampling method and the sample used in this study amounted to 14 companies for 5 years. The method of analysis uses multiple regression.

The results showed that profitability and liquidity as a measure of the company's financial performance did not affect the disclosure of sustainability bother while the solvency had an effect on disclosure of sustainability bother. Profitability and solvency affect the value of the company, but liquidity and sustainability report disclosure do not affect the value of the company. This study also shows that sustainability report disclosure cannot mediate the effect of financial performance on firm value.
\end{abstract}

Keywords: Financial Performance, Sustainability Report, Company Value

\section{PENDAHULUAN}

Persaingan antar perusahaan di era digital yang semakin ketat diperlukan kreatifitas untuk mencapai tujuan perusahaan, yaitu memaksimalkan nilai perusahaan yang tercermin pada harga sahamnya. Nilai perusahaan merupakan harga yang bersedia dibayar oleh calon pembeli jika perusahaan tersebut dijual (Nurlela \& Islahuddin, 2008). Salah satu faktor yang dapat mempengaruhi nilai perusahaan adalah kinerja keuangan perusahaan yang dapat dilihat pada likuiditas, solvabilitas, dan profitabilitas. Kinerja keuangan dapat sebagai pedoman transaksi jual-beli saham suatu perusahaan (Lybryanta, et al, 2015). Oleh karena itu, penelitian ini menggunakan variabel untuk melihat kinerja keuangan.

Penelitian ini dilatarbelakangi oleh perbedaan hasil-hasil penelitian sebelumnya. tentang perkembangan nilai perusahaan yang menunjukkan hasil beragam. Penelitian tentang pengaruh profitabilitas terhadap nilai perusahaan dilakukan oleh Dhani \& Utama (2017), Ayu \& Suarjaya (2017), Hamidah \& Umdiana (2017), Suwardika \& Mustanda (2017), dan Meidiawati \& Mildawati (2016) menunjukkan bahwa profitabilitas berpengaruh positif signifikan terhadap nilai perusahaan. Artinya, semakin tinggi nilai profitabilitas maka semakin tinggi juga nilai perusahaan. Namun hasil penelitian berbeda mengenai pengaruh profitabilitas terhadap nilai perusahaan ditunjukkan oleh Jariah (2016) dan Hermawan \& Maf'ulah (2014) yang menyimpulkan bahwa profitabilitas yang diproksikan dengan ROA tidak berpengaruh terhadap nilai perusahaan. Carningsih (2012) dalam penelitiannya justru menemukan bahwa profitabilitas yang diproksikan dengan ROA berpengaruh 
negatif terhadap nilai perusahaan. Artinya, semakin tinggi profitabilitas maka semakin rendah nilai perusahaan.

Penelitian lain mengenai pengaruh likuiditas terhadap nilai perusahaan yang telah diteliti menunjukkan fenomena yang berbeda-beda. Jantana (2017), Jariah (2016), dan Nugroho (2012) dalam penelitiannya menyimpulkan bahwa likuiditas berpengaruh positif dan signifikan terhadap nilai perusahaan dan penelitian Lybryanta, et al., (2015) menyimpulkan bahwa likuiditas berpengaruh negatif signifikan terhadap nilai perusahaan artinya bahwa semakin tinggi likuiditas maka nilai perusahaan akan semakin menurun. Berbeda dengan hasil penelitian yang dilakukan oleh Firnanda \& Oetomo (2016 dan Mahendra DJ (2012) menyimpulkan bahwa likuiditas tidak berpengaruh secara signifikan terhadap nilai perusahaan. Berdasarkan hasil penelitian tersebut menunjukkan adanya gap antar peneliti.

Demikian halnya dengan pengaruh variabel solvabilitas terhadap nilai perusahaan menunjukkan hasil yang tidak konsisten antar peneliti. Aditya \& Naomi (2017), Suwardika \& Mustanda (2017), Meidiawati \& Mildawati (2016), Suffah \& Riduwan (2016), Pratama \& Wirawati (2016), serta Jariah (2016) dalam penelitiannya membuktikan bahwa variabel solvabilitas yang diproksikan dengan DER memiliki pengaruh positif signifikan terhadap nilai perusahaan. Hasil penelitian berbeda mengenai pengaruh variabel solvabilitas terhadap nilai perusahaan ditunjukkan oleh Dhani \& Utama (2017) yang dalam penelitiannya memberikan kesimpulan bahwa DER sebagai proksi dari solvabilitas tidak cukup untuk mempengaruhi besarnya nilai perusahaan. Mahendra DJ (2011) dan Widhiastuti, dkk (2018) juga menunjukkan hasil penelitian bahwa solvabilitas berpengaruh negatif tidak signifikan terhadap nilai perusahaan. Hal ini menunjukkan bahwa semakin banyak hutang maka nilai perusahaan akanmenurun, dan kecilnya hutang yang dimiliki perusahaan tidak terlalu diperhatikan oleh investor.
Dengan adanya fenomena gap hasil penelitian terhadap teori mengenai pengaruh kinerja keuangan terhadap nilai perusahaan yang kontradiktif, menjadikan penelitian mengenai pengaruh kinerja keuangan terhadap nilai perusahaan menjadi menarik dan perlu dilakukan. Diduga ada variabel lain yang memediasi pengaruh kinerja keuangan terhadap nilai perusahaan.

Meskipun nilai perusahaan sangat penting, namun penilaian perusahaan didasarkan pada persepsi investor terhadap tingkat keberhasilan perusahaan terkait harga saham (Sujoko \& Soebiantoro, 2007). Persepsi adalah gambaran dan pemahaman tentang lingkungan berdasarkan tindakan menyusun, mengenali, dan menafsirkan informasi sensoris(Schacter, Gilbert, Wagner, \& Nock, 2011).

Fenomena saat ini telah terjadi pergeseran cukup signifikan dalam penentuan nilai pasar sebuah entitas bisnis. Pada tahun 1975, nilai perusahaan ditentukanoleh aspek keuangan sebesar 83\%, sedangkan sisanya ditentukan oleh aspek nonkeuangan sebesar $17 \%$. Namun padatahun 2009 , terjadi pergeseran dimana nilai pasar entitas perusahaan hanya ditentukan 19\% oleh aspek keuangan dan sisanya $81 \%$ oleh aspek nonkeuangan (Tomo, Ocean;, 2011). Selain itu, berdasarkan survei yang dilakukan kepada 1000 Chief Executive Owner (CEO) di 103 negara dan 27 industri, $80 \%$ dari CEO memiliki pandangan bahwa sustainability merupakan cara untuk memperoleh keuntungan kompetitif dari para pesaing (Accenture, 2013). Hasil survey ini juga menjelaskan bahwa sustainability saat ini merupakan bagian yang tidak terpisahkan dari dunia usaha. Menurut Epstein \& Freedman (1994), saat ini keputusan investasi yang hanya didasarkan oleh informasi ekonomi saja udah tidak relevan lagi karena para investor individual mulai tertarik dengan informasi sosial.

Komitmen perusahaan dalam melaksanakan usaha yang berkelanjutan dituangkan dalam sebuah laporan yang disebut sustainability report. Elkington 
(1997) mengatakan bahwa sustainability report tidak hanya memuat informasi mengenai kinerja keuangan saja, tetapi juga informasi non keuangan yang terdiri dari informasi aktivitas sosial dan lingkungan yang memungkinkan perusahaan bisa bertumbuh secara berkesinambungan. Sustainability (keberlanjutan) adalah keseimbangan antara people-planet-profit, yang dikenal dengan konsep triple bottom line (TBL). Untuk memenangi persaingan kompetitif, konsep triple bottom line harus menjadi bagian dari strategi perusahaan (Kramer \& Porter, 2006).

Pengungkapan sustainability report oleh perusahaan di Indonesia setiap tahunnya semakin meningkat. Tren ini dapat dilihat dari data peserta Indonesia Sustainability Report Award yang diselenggarakan oleh National Center for Sustainability Report(http://www.ncsr-id.org) yang pertama kali diadakan pada tahun 2008 hanya terdiri dari 18 perusahaan dan di tahun 2015 sudah mencapai 37 perusahaan.

Indeks saham Sustainable and Responsible Investment(SRI-KEHATI) merupakan salah satu indeks yang menjadi indikator pergerakan harga saham di Bursa Efek Indonesia (BEI), yang menggunakan prinsip keberlanjutan, keuangan, dan tata kelola yang baik, serta kepedulian terhadap lingkungan hidup sebagai tolok ukurnya. Indeks SRI-KEHATI merupakan benchmark investasi bagi para investor ataupun manajer investasi dalam menentukan perusahaan publik mana yang memiliki kinerja baik dalam menjalankan usahanya dari sisi tata kelola finansial, sosial, dan lingkungan secara berkelanjutan.

Pengungkapan sustainability report saat ini belum diwajibkan bagi perusahaan yang listing di Bursa Efek Indonesia, sehingga sifatnya masih sukarela (voluntary disclosure) (Chariri \& Nugroho, 2009). Pengungkapan Sustainability Report memiliki korelasi terhadap kinerja keuangan perusahaan(Weber, Koellner, Habegger, \& Ohnemus, 2008). Pada penelitian lain, Pratiwi \& Sumaryati (2014) serta Safitri (2015) menjelaskan bahwa pengungkapan
Sustainability Report berpengaruh signifikan terhadap kinerja keuangan.

Meskipun pengungkapan Sustainability Report memiliki korelasi terhadap kinerja keuangan, banyak penelitian lanjutan di Indonesia yang justru menunjukkan bahwa pengungkapan Sustainability Report tidak berpengaruh signifikan terhadap nilai perusahaan. Penelitian yang dilakukan oleh Ramadhani (2016) menunjukkan bahwa pengungkapan Sustainability Report tidak berpengaruh terhadap nilai perusahaan. Penelitian lain yang dilakukan oleh Astuti \& Juwenah (2017) juga menyimpulkan bahwa tidak semua aspek dari pengungkapan Sustainability Report berpengaruh terhadap nilai perusahaan. Hanya aspek pengungkapan ekonomi yang berpengaruh terhadap nilai perusahaan.

Fenomena semakin meningkatnya pengungkapan sustainability report oleh perusahaan-perusahaan yang terdaftar di Bursa Efek Indonesia dan berkembangnya penelitian mengenai pengungkapan sustainability report menjadi dasar dugaan bahwa pengungkapan sustainability reportmerupakan faktor yang menjadi mediator antara kinerja keuangan dan nilai perusahaan.

Berdasakan uraian latar belakang masalah terdapat perbedaan hasil dari penelitian terdahulu mengenai masalah nilai perusahaan, maka tujuan penelitian ini adalah: (1) Untuk mengetahui dan menganalisis pengaruh profitabilitas, solvabilitas dan likuiditas terhadap pengungkapan sustainability report. (2) Untuk mengetahui dan menganalisis pengaruh profitabilitas, solvabilitas dan likuiditas terhadap nilai perusahaan. (3) Untuk mengetahui dan menganalisis pengaruh pengungkapan sustainability report terhadap nilai perusahaan. (4) Untuk mengetahui dan menganalisis pengaruh profitabilitas, solvabilitas, dan likuiditas terhadap nilai perusahaan yang dimediasi oleh pengungkapan sustainability report. 
TINJAUAN PUSTAKA

Signalling Theory

Menurut Jama'an (2008), signalling theory mengemukakan bagaimana seharusnya sebuah perusahaan memberikan sinyal kepada pengguna laporan keuangan. Sinyal-sinyal dalam laporan keuangan berisi informasi tentang bagaimana manajemen melaksanakan dan merealisasikan tujuan pemegang saham. Dalam sinyal yang terdapat dalam laporan keuangan, akan tersirat sinyal yang menunjukkan bahwa perusahaan tersebut lebih baik dari perusahaan lain. Teori sinyal juga menjelaskan mengenai laporan keuangan yang seharusnya bisa mengurangi asimetri informasi melalui kebijakan konservatisme yang menghasilkan laba berkualitas (tidak overstate).

\section{Nilai Perusahaan}

Nilai perusahaan adalah persepsi investor terhadap tingkat keberhasilan perusahaan yang sering dikaitkan dengan harga saham (Sujoko \& Soebiantoro, 2007). Harga saham yang tinggi membuat nilai perusahaan juga tinggi. Maksimalisasi nilai perusahaan sangat penting bagi perusahaan karena dengan memaksimalkan nilai perusahaan berarti juga memaksimalkan tujuan utama perusahaan, yaitu kesejahteraan para pemilik sahamnya (Sartono, 2010). Metode yang digunakan untuk mengukur nilai perusahaan menggunakan price to book value (PBV).

Menggambarkan seberapa besar pasar menghargai nilai buku perusahaan, apakah overvalued (di atas) atau undervalued (di bawah) nilai buku (Brigham \& Houston, 2001). Makin tinggi PBV, maka semakin tinggi pula pasar memandang prospek perusahaan di masa yang akan datang.

\section{Kinerja Keuangan}

Kinerja keuangan adalah pencapaian perusahaan pada periode tertentu yang menggambarkan kondisi kesehatan keuangan perusahaan. Baik atau buruknya kesehatan sebuah perusahaan dapat digambarkan oleh kinerja keuangan dengan menggunakan alat analisis keuangan. Hal ini sangat penting agar sumber daya digunakan secara optimal dalam menghadapi perubahan (Fahmi, 2011).

Menurut Munawir (2012), tujuan dari pengukuran kinerja keuangan perusahaan adalah untuk mengetahui tingkat likuiditas, solvabilitas, profitabilitas, dan stabilitas.

\section{Profitabilitas}

Profitabilitas merupakan rasio yang mengukur kemampuan perusahaan untuk menghasilkan laba (Sudana, 2011). Semakin tinggi kemampuan memperoleh laba, maka semakin besar return yang diharapkan investor. Keefektivan kinerja perusahaan dan manajemen menerapkan kebijakan dalam menghasilkan laba dengan menggunakan aset-aset yang tersedia tercermin pada rasio profitabilitas. Rasio profitabilitasm(Van Horne dan Wachowicz (2005) adalah rasio yang menghubungkan antara laba dari penjualan dan investasi. Pertumbuhan profitabilitas perusahaan adalah indikator penting dari sudut pandang investor dalam melihat prospek perusahaan di masa mendatang. Pengukuran Profit pada penelitian ini menggunakan Return on Asset (ROA), (Kasmir, 2008). Return on Asset (ROA) adalah rasio antara laba bersih setelah pajak dengan jumlah asset perusahaan secara keseluruhan.

\section{Solvabilitas}

Solvabilitasdapat diartikan sebagai pengungkit. Pengungkit dalam sebuah perusahaan merupakan penggunaan sumber daya perusahaan yang terukur dalam meningkatkan operasional. Harahap (2013) menyatakan bahwa solvabilitas adalah rasio antara utang perusahaan terhadap modal. Rasio ini dapat melihat seberapa jauh perusahaan dibiayai oleh utang atau pihak luar, dengan kemampuan modal perusahaan. Analisis solvabilitas pada penelitian ini menggunakan DER (Fahmi, 2011). Debt to Equity Ratio (DER) adalah rasio utang sebagai sumber modal (utang jangka panjang dan utang jangka pendek) dengan modal sendiri. DER biasanya digunakan untuk mengukur financial leverage dari suatu perusahaan. Long Term Debt to Equity Ratio 
(LDER) merupakan rasio yang digunakan untuk mengukur tingkat kewajiban jangka panjang dibandingkan dengan total modal.Short Term Debt to Equity Ratio (CDER) merupakan rasio yang digunakan untuk mengukur tingkat kewajiban jangka pendek dibandingkan dengan total modal.

\section{Likuiditas}

Likuiditas adalah rasio yang menunjukkan kemampuan perusahaan untuk membayar semua kewajiban finansial jangka pendek pada saat jatuh tempo dengan menggunakan aktiva lancar yang tersedia (Brigham dan Houston, 2001). Likuiditas tidak hanya berkenaan dengan keadaan keseluruhan keuangan perusahaan, tetapi juga berkaitan dengan kemampuan untuk mengubah aktiva lancar tertentu menjadi uang kas yang likuid. Likuiditas adalah salah satu faktor yang menentukan sukses atau gagalnya suatu perusahaan menyediakan kebutuhan uang tunai untuk memenuhi kebutuhan jangka pendek. Untuk mengukur likuiditas pada penelitian ini menggunakan Current Ratio (CR), (Munawir, 2012). Current Ratio (Rasio Lancar) menggambarkan bagaimana aktiva lancar perusahaan dapat digunakan untuk menutupi kewajiban jangka pendek atau utang lancarnya.

\section{Sustainability Report}

Sustainability report adalah laporan yang dibuat oleh perusahaan untuk mengukur, mengungkapkan (disclose), serta upaya perusahaan untuk menjadi perusahaan yang akuntabel bagi seluruh pemangku kepentingan (stakeholders) untuk perusahaan yang berkelanjutan (Effendi, 2009). Sustainability report diharapkan membawa perusahaan berkembang secara berkelanjutan dengan dasar etika bisnis.

Menurut Effendi (2009), ada lima penyajian sustainable report, yaitu: a) penyusunan kebijakan perusahaan b) tekanan pada rantai pemasok (supply chain), c) keterlibatan stakeholders, d) Voluntary codes, dan e) mekanisme lain berupa penilaian dan pembandingan, pajak dan subsidi, lisensi yang dapat diperdagangkandan kewajiban serta pembatasan.

Sustainability Report mengikuti standar yang dibuat oleh Global Reporting Inititative (GRI). Standar ini mengukur praktik sustanaibility management berupa GRI Sustainability Reporting Guidelines yang mencakup beberapa elemen penting yang berhubungan dengan 3 aspek yaitu ekonomi, lingkungan dan manusia atau triple bottom line (Profit, Planet \& People). Indikator dan aspek yang dilaporkan dalam Sustainability Report versi GRI adalah: a) Indikator kinerja ekonomi, b) Indikator kinerja lingkungan, c) Indikator sosial praktik perburuhan dan pekerjaan yang layak, d) Indikator sosial hak asasi manusia, e) Indikator sosial kinerja masyarakat, f) Indikator sosial kinerja responsibilitas produk.

\section{Index SRI-KEHATI}

PT. Bursa Efek Indonesia bekerjasama dengan Yayasan Keanekaragaman Hayati Indonesia (Yayasan KEHATI), meluncurkan indeks harga saham yang diberi nama Indeks SRI-KEHATI. SRI adalah kependekan dari Sustainable and Responsible Investment. Indeks ini merupakan sebuah benchmark bagi para calon investor yang ingin menilik kinerja perusahaan yang memiliki kesadaran terhadap lingkungan hidup, sosial, dan tata kelola perusahaan yang baik.

Ada tiga tahap pemilihan dan review agar sebuah perusahaan dapat masuk dalam indeks SRI-KEHATI, yaitu:

1) Aspek bisnis inti (core business) tidak masuk dalam 9 kategori, yaitu pestisida, nuklir, senjata, tembakau, alkohol, pornografi, perjudian, genetically modified organism (GMO), dan pertambangan batubara.

2) Aspek finansial, di mana hanya emiten yang memiliki kapitalisasi pasar dan total aset lebih besar dari Rp 1 triliun, free float ratio lebih besar dari 10 persen, serta rasio price earning (PE) positif, yang memiliki peluang untuk lolos ke tahap seleksi berikutnya. 
3) Aspek fundamental dimana emiten bersangkutan akan dinilai berdasarkan enam indikator fundamental dalam Indeks SRI-KEHATI, yang meliputi: tata kelola perusahaan, lingkungan, keterlibatan masyarakat, perilaku bisnis, sumber daya manusia, dan hak asasi manusia (https://www.kehati.or.id/mengenalindeks-sri-kehati/).

Penilaian indikator ini dilakukan melalui review terhadap data sekunder, pengisian kuesioner oleh emiten-emiten, dan data-data lain yang relevan. Dari hasil review tersebut, terpilihlah 25 emiten sebagai konstituen penyusun Indeks SRI-KEHATI.

\section{Kerangka Pemikiran}

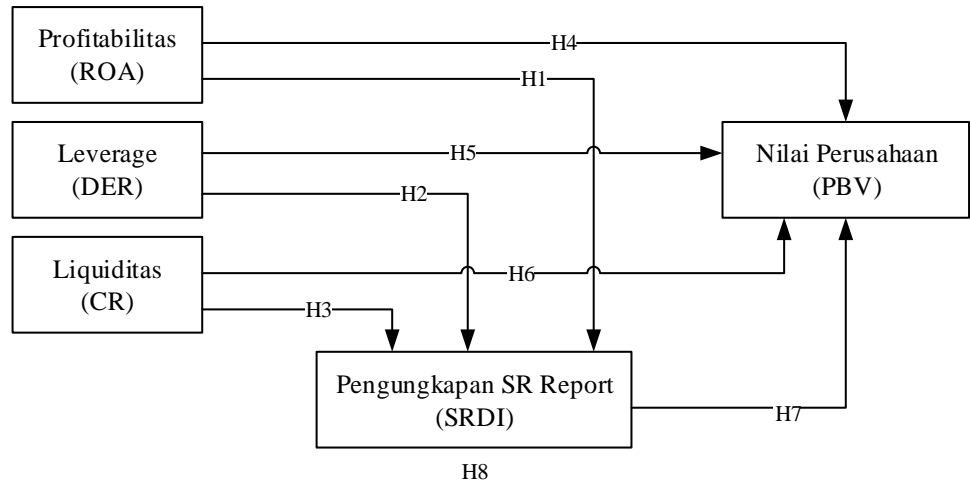

Gambar 1. Kerangka Pemikiran Dan Sumber Penelitan Sumber: Dikembangkan Penulis untuk Penelitian (2018)

Tabel 1. Pengembangan Hipotesis

\begin{tabular}{|c|c|c|}
\hline & Alur & Sumber \\
\hline H1 & ROA $\rightarrow$ SRDI & Tomo (2011), Epstein \& Freedman (1994) \\
\hline H2 & DER $\rightarrow$ SRDI & Aniktia and Khafid (2015) \\
\hline H3 & CR $\rightarrow$ SRDI & Saputro, et al (2013) \\
\hline H4 & ROA $\rightarrow$ PBV & $\begin{array}{c}\text { Alamsyah (2017), Dhani \& Utama (2017), } \\
\text { Ayu \& Suarjaya (2017), Hamidah \& } \\
\text { Umdiana (2017), serta Suwardika \& } \\
\text { Mustanda (2017). }\end{array}$ \\
\hline H5 & DER $\rightarrow$ PBV & $\begin{array}{c}\text { Aditya \& Naomi (2017), Suwardika \& } \\
\text { Mustanda(2017), serta Pratama \& } \\
\text { Wirawati (2016) }\end{array}$ \\
\hline H6 & CR $\rightarrow$ PBV & Jantana (2017) dan Jariah (2016) \\
\hline H8 & SRDI $\rightarrow$ PBV & Safitri (2015) \\
\hline SOA+DER+CR) $\rightarrow$ SRDI $\rightarrow$ & Elkington (1997), Accenture (2013) \\
\hline
\end{tabular}

Sumber: Dikembangkan Penulis untuk Penelitian (2018)

\section{Pengembangan Hipotesis}

Berdasarkan pemaparan latar belakang masalah dan tinjauan pustaka, maka hipotesis yang dikembangkan adalah:

$\mathrm{H}_{1}$ :Terdapat pengaruh profitabilitas terhadap pengungkapan sustainability report
$\mathrm{H}_{2}$ :Terdapat pengaruh solvabilitas terhadap pengungkapan sustainability report

$\mathrm{H}_{3}$ :Terdapat pengaruh likuiditas terhadap pengungkapan sustainability report 
$\mathrm{H}_{4}$ :Terdapat pengaruh profitabilitas terhadap nilai perusahaan

$\mathrm{H}_{5}$ :Terdapat pengaruh solvabilitasterhadap nilai perusahaan

$\mathrm{H}_{6} \quad$ :Terdapat pengaruh likuiditasterhadap nilai perusahaan

$\mathrm{H}_{7}$ :Terdapat pengaruh pengungkapan sustainability report terhadap nilai perusahaan

$\mathrm{H}_{8}$ :Terdapat pengaruh profitabilitas, solvabilitas, dan likuiditas terhadap nilai perusahaan yang dimediasi oleh pengungkapan sustainability report

\section{METODE PENELITIAN Jenis dan Sumber Data}

Jenis data yang digunakan dalam penelitian ini adalah data sekunder. Sumber data diperoleh dari Bursa Efek Indonesia (www.idx.co.id) berupa laporan keuangan mulai tahun 2012 sampai dengan 2016. Khusus data pengungkapan sustainability report diperoleh dari laman Yayasan Kehati (www.kehati.or.id) dan laman masingmasing perusahaan.

\section{Populasi dan Sampel}

Populasi yang digunakan dalam penelitian ini adalah perusahaan-perusahaan yang terdaftar di Bursa Efek Indonesia dan masuk dalam indeks SRI-KEHATI tahun 2012-2016. Pemilihan sampel menggunakan metode purposive sampling dengan tujuan untuk mendapatkan sampel yang sesuai dengan kriteria yang telah ditentukan, yaitu:(1) Perusahaan yang konsisten terdaftar dalam indeks SRI-KEHATI di Bursa Efek Indonesia tahun 2012-2016.(2) Perusahaan non sektor keuangan dalam indeks SRIKEHATI di Bursa Efek Indonesia tahun 2012-2016.(3) Perusahaanyangmenerbitkan laporan tahunan pada tahun 2012-2016.(4) Perusahaan yang menerbitkan Sustainability Report pada tahun 2012-2016.

\section{Disain Penelitian dan Identifikasi Variabel}

Jenis penelitian yang digunakan dalam penelitian ini adalah explanatory research tipe kausal yang berupaya menguji pengaruh antar variabel dalam sebuah model struktural
(Mulyanto \& Wulandari, 2010). Variabelvariabel yang digunakan dalam penelitian ini adalah: (1) Variabel Exogen: Profitabilitas, Solvabilitas, dan Likuiditas, (2) Variabel Endogen: Pengungkapan Sustainability Report dan Nilai Perusahaan.

\section{Definisi Operasional Variabel Nilai Perusahaan}

Nilai perusahaan adalah perbandingan antara harga pasar per lembar saham dengan nilai buku per lembar saham. Nilai perusahaan dapat diukur dengan Price to Book Value (PBV), yaitu mengukur nilai yang diberikan pasar kepada manajemen dan organisasi perusahaan sebagai sebuah perusahaan yang terus tumbuh (Brigham dan Houston, 2001). PBV dapat dihitung dengan rumus sebagai berikut:

$$
P B V=\frac{\text { Nilai Pasar Saham }}{\text { Nilai Buku Saham }} 100 \%
$$

\section{Kinerja Keuangan}

Kinerja keuangan yang digunakan dalam penelitian ini adalah profitabilitas, solvabilitas, dan likuiditas.

\section{Profitabilitas}

Variabel profitabilitas ini diukur dengan melihat kemampuan modal yang diinvestasikan perusahaan dalam keseluruhan jumlah aktiva untuk menghasilkan Return On Asset (ROA). Secara matematis, profitabilitas (ROA) dapat dihitung dengan menggunakan rumus sebagai berikut (Brigham dan Houston, 2001):

$$
\text { ROA }=\frac{\text { Laba Bersih }}{\text { Total Aktiva }} 100 \%
$$

\section{Solvabilitas}

Solvabilitas merupakan ukuran yang memperlihatkan sejauh mana perusahaan dalam membiayai aktivanya menggunakan pembiayaan utang (total utang) dalam struktur modal perusahaan untuk membiayai kegiataan perusahaan (Brigham dan Houston, 2001). Solvabilitas perusahaan menunjukkan hutang yang dimiliki perusahaan yang diukur dengan Debt To Equity Ratio (DER). Secara matematis, Debt To Equity Ratio (DER) 
dapat dihitung dengan menggunakan rumus sebagai berikut:

$$
\text { DER }=\frac{\text { Total Kewajiban }}{\text { Ekuitas Pemegang Saham }} 100 \%
$$

\section{Likuiditas}

\section{Likuiditas}

kemampuan suatu perusahaan untuk memenuhi kewajiban finansialnya yang segera harus dipenuhi. Likuiditas dalam penelitian ini diwakili oleh current ratio (CR). Rasio ini menujukkan besarnya kewajiban lancar yang ditutup dengan aktiva yang diharapkan akan dikonversi menjadi kas dalam jangka pendek. Rasio ini dihitung dengan cara membagi aktiva lancar dengan kewajiban lancar (Brigham dan Houston, 2001). Secara matematis, current ratio (CR) dapat dihitung dengan menggunakan rumus sebagai berikut:

$$
C R=\frac{\text { Aktiva Lancar }}{\text { Hutang Lancar }} 100 \%
$$

\section{Pengungkapan Sustainability Report}

Perhitungan pengungkapan sustainability report dilakukan dengan mengukur sejauh apa pengungkapan yang telah dilakukan oleh perusahaan. Perhitungan sustainability report disclosure index (SRDI) dapat dilakukan dengan menggunakan variabel dummy sesuai dengan penelitian Nurlela dan Islahudin (2008), yaitu:

Skor 1: jika perusahaan mengungkapkan item pada sustainability report

Skor0: jika perusahaan tidak mengungkapkan item pada sustainability report

Setelah pengungkapan sustainability report dinilai berdasarkan daftar indeks, maka jumlah skor akhir akan dihitung dengan menjumlahkan skor dari pengungkapan sustainability report yang dilakukan perusahaan dibagi dengan pengungkapan yang seharusnya dilakukan (total pengungkapan sustainability report berdasarkan indeks pengungkapan menurut GRI) dengan penghitungan sebagai berikut:

$$
S R D I=\frac{\Sigma x}{n} 100 \%
$$

\section{Metode Analisis \& Pengujian Hipotesis}

Analisis yang digunakan dalam penelitian ini adalah analisis statistik deskriptif dan analisis verifikatif, yaitu analisis regresi linear berganda yang diperluas dengan Sobel Test untuk mengetahui signifikansi pengaruh variabel intervening.

\section{Analisis Deskriptif}

Analisis statistik deskriptif digunakan dalam penelitian ini untuk memberikan gambaran atau deskripsi mengenai variabelvariabel penelitian, yaitu profitabilitas, solvabilitas, likuiditas, pengungkapan sustainability report, dan nilai perusahaan. Analisis ini disajikan dalam bentuk nilai minimum, maksimum, rata-rata, dan standar deviasi.

\section{Uji Asumsi Klasik}

Sebelum dilakukannya analisis verifikatif, dilakukan uji persyaratan analisis yaitu uji asumsi klasik. Uji asumsi klasik digunakan untuk membuktikan bahwa model persaman dapat diterima secara ekonometrika karena memenuhi penaksiran BLUE (Best Linier Unbiased Estimator) artinya penaksiran tidak bias, linier dan konsisten. Uji asumsi terdiri dari uji normalitas, linieritas, multikolinieritas, autokorelasi, dan heteroskedastisitas (Mulyanto dan Wulandari, 2010: 181).

\section{Uji Model}

Setelah uji asumsi terpenuhi maka dilakukan analisis regresi. Dari hasil analisis regresi tersebut akan diuji modelnya apakah memenuhi persyaratan atau tidak untuk uji hipotesis. Dalam penelitian ini terdapat dua substruktur persamaan yang harus diuji modelnya, yaitu:

1) $Z=\alpha+\beta 4 X 1+\beta 5 X 2+\beta 6 X 3+\varepsilon 1$

2) $\mathrm{Y}=\alpha+\beta 1 \mathrm{X} 1+\beta 2 \mathrm{X} 2+\beta 3 \mathrm{X} 3+\beta 7 \mathrm{Z}+\varepsilon 2$

Dari masing-masing model substruktur tersebut, akan diuji dengan uji koefisien determinasi $\left(\mathrm{R}^{2}\right)$ dan uji simultan

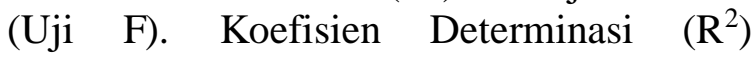
digunakan untuk mengukur tingkat 
kemampuan model dalam menerangkan variabel independen. (Ghozali, 2011). Dan Uji Simultan (Uji F) untuk mengetahui apakah terdapat pengaruh secara bersamasama dari variabel independen terhadap variabel dependen. Uji F dilakukan dengan membandingkan nilai probabilitas (sig F) terhadap taraf uji penelitian $(\alpha=0.05)$. Kriteria yang digunakan untuk menguji kelayakan model adalah sebagai berikut: a) Jika Sig $\mathrm{F}<\alpha$ maka Ho ditolak dan $\mathrm{Ha}$ diterima, artinya model hasil penelitian layak digunakan untuk menjelaskan Pengaruh Kinerja Keuangan terhadap Nilai Perusahaan yang dimediasi oleh pengungkapan Sustainability Report, dan Uji t untuk pengujian hipotesis dengan uji$\mathrm{t}$, yaitu membandingkan nilai probabilitas $(\operatorname{sig} t)$ terhadap taraf uji penelitian $(\alpha=$ 0.05).

\section{Uji Sobel}

Uji Sobel digunakan untuk mengetahui pengaruh tidak langsung kinerja keuangan (ROA, DER, CR) terhadap nilai perusahaan (PBV) melalui pengungkapan sustainability report (SRDI). Uji Sobel dilakukan dengan cara menguji kekuatan pengaruh tidak langsung Profitabilitas, Solvabilitas, dan Likuiditas $(\mathrm{X} 1+\mathrm{X} 2+\mathrm{X} 3)$ ke Nilai Perusahaan (Y) lewat pengungkapan Sustainability Report (Z). Pengaruh tidak langsung $\mathrm{X} 1+\mathrm{X} 2+\mathrm{X} 3$ ke $\mathrm{Y}$ lewat $\mathrm{Z}$ dihitung dengan cara mengalikan jalur $\mathrm{X} 1+\mathrm{X} 2+\mathrm{X} 3 \rightarrow \mathrm{Z}$ (a) dengan jalur $\mathrm{Z} \rightarrow \mathrm{Y}$ (b) atau ab. Jadi koefisien $a b=(c-c ')$ dimana $c$ adalah pengaruh $\mathrm{X} 1+\mathrm{X} 2+\mathrm{X} 3$ terhadap $\mathrm{Y}$ tanpa mengontrol $\mathrm{Z}$, sedangkan c' adalah koefisien pengaruh $\mathrm{X} 1+\mathrm{X} 2+\mathrm{X} 3$ terhadap $\mathrm{Y}$ setelah mengontrol Z. Standard error koefisien a dan $\mathrm{b}$ ditulis dengan $\mathrm{Sa}$ dan $\mathrm{Sb}$, besarnya standard error pengaruh tidak langsung (indirect effect) Sab dihitung dengan rumus dibawah ini:

$$
S a b=\sqrt{b^{2} S a^{2}+a^{2} S b^{2}+S a^{2} S b^{2}}
$$

Untuk menguji signifikansi pengaruh tidak langsung, maka perlu menghitung nilai $\mathrm{t}$ dari koefisien $\mathrm{ab}$ dengan rumus sebagai berikut: $z=a b / S a b$. Nilai z hitung ini dibandingkan

dengan nilai $t$ tabel yaitu $\geq 1,96$.

\section{HASIL PENELITIAN}

\section{Uji Asumsi Klasik}

Berdasarkan Uji normalitas dilakukan dengan melihat penyebaran data (titik) pada sumbu diagonal dari grafik. Berdasarkan Normal Plot menunjukkan bahwa data (titik) menyebar di sekitar dan mendekati garis diagonal. Ini menunjukkan bahwa data penelitian menunjukkan distribusi data normal. Berdasarkan hasil uji Multikolinieritas yang dilakukan dengan melihat nilai VIF nya. Nilai cutoff yang umum dipakai untuk menunjukkan adanya multikolinearitas adalah nilai tolerance $\leq$ 0,10 atau sama dengan nilai VIF $\geq 10$ (Ghozali, 2011). Hasil uji multikolinearitas pada variabel independen diperoleh nilai tolerance pada variabel penelitian di atas 0,1 dan nilai VIF di bawah 10 sehingga dapat dikatakan tidak terjadi korelasi antar variabel bebas. Berdasarkan hasil Uji Heteroskedastisitas yang yang diuji dengan metode grafis bertujuan menguji apakah dalam model regresi terjadi ketidaksamaan variance dari residual satu pengamatan ke pengamatan yang lain (Ghozali, 2011). Dari penelitian inin terlihat titik-titik menyebar tanpa membentuk pola tertentu dan menyebar di atas dan di bawah angka 0 pada sumbu Y. Dengan demikian data-data pada penelitian ini tidak terjadi heteroskedastisitas. Uji berikutnya menggunakan Uji Autokorelasi untuk mengetahui apakah dalam model regresi linier ada korelasi antara kesalahan pengganggu pada periode $t$ dengan kesalahan pengganggu pada periode t-1 (sebelumnya). Berdasarkan nilai Durbin Watson pada kedua model regresi berada pada kriterian $\mathrm{du}<\mathrm{dw}<4-\mathrm{du}$. Oleh karena itu, dapat dikatakan tidak adanya permasalahan autokorelasi pada kedua model regresi, sehingga model regresi linier tidak ada korelasi antara kesalahan pengganggu pada periode $t$ dengan kesalahan pengganggu pada periode t-1 (sebelumnya). 
Uji Model

Pada penelitian ini terdapat 2 substruktur analisis dengan model persamaannya adalah :
Uji model substruktur 1 adalah uji terhadap pengaruh profitabilitas (ROA), solvabilitas (DER), likuiditas (CR) terhadap nilai perusahaan (PBV). Substruktur 1 ini memiliki persamaan sebagai berikut:

$\mathrm{Z}=\alpha+\beta 1 \mathrm{X} 1+\beta 2 \mathrm{X} 2+\beta 3 \mathrm{X} 3+\varepsilon 1$

Rangkuman hasil perhitungan regresi untuk persamaan substruktur 1 adalah sebagai berikut:

\section{Uji Model Substruktur 1}

\section{Tabel 2. Regresi X1,X2,X3 Terhadap Z}

\begin{tabular}{|c|c|c|c|c|c|}
\hline Variabel & $\begin{array}{c}\text { Unstandardized } \\
(\mathbf{B})\end{array}$ & $\begin{array}{c}\text { Standardized } \\
(\text { Beta })\end{array}$ & $\begin{array}{c}\text { Std. } \\
\text { Error }\end{array}$ & $\begin{array}{c}\mathbf{t} \\
\text { hitung }\end{array}$ & Sig. \\
\hline $\mathrm{X} 1$ & 0,097 & 0,092 & 0,111 & 0,876 & 0,383 \\
\hline $\mathrm{X} 2$ & $-0,062$ & $-0,572$ & 0,012 & $-5,017$ & 0,000 \\
\hline $\mathrm{X} 3$ & $-0,021$ & $-0,155$ & 0,015 & $-1,348$ & 0,182 \\
\hline Konstanta & 107,707 & \multicolumn{5}{|l}{} \\
\hline Fhitung;Sig & 8,$910 ; 0,000$ & \multicolumn{5}{|l}{} \\
\hline Adjusted R ${ }^{2}$ & 0,256 &
\end{tabular}

Sumber: Data Sekunder Olah (2018)

Berdasarkan hasil di atas, model regresi sebagai berikut :

$Z=107,707+0,097 X_{1}-0,062 X_{2}-0,021 X_{3}$

\section{Koefisien Determinasi (Adjusted $\mathbf{R}^{\mathbf{2}}$ )}

Nilai koefisien determinasi untuk model substruktur 1 yaitu 0,256 , sehingga dapat diartikan bahwa variabel kinerja keuangan (ROA, DER, dan CR) secara simultan dapat mempengaruhi pengungkapan sustainability report sebesar 25,6 \% sedangkan sisanya yaitu $74,4 \%$ variabel pengungkapan sustainability report dipengaruhi oleh variabel lainnya

\section{Uji Simultan (Uji F)}

Berdasarkan perhitungan model substruktur 1, diperoleh nilai signifikansi untuk uji $\mathrm{F}$ yaitu 0,000 dan Fhitung 8,910 sehingga nilai signifikansi lebih kecil dari 0,05 dan dapat dikatakan bahwa variabel kinerja keuangan (ROA, DER, dan CR) secara simultan dapat mempengaruhi pengungkapan sustainability report. Hal ini juga mengartikan bahwa model regresi $\mathrm{Z}=$ $107,707+0,097 X_{1}-0,062 X_{2}-0,021 X_{3}$ layak digunakan.

\section{Uji Model Substruktur 2}

Uji model substruktur 2 adalah uji terhadap pengaruh profitabilitas (ROA), solvabilitas(DER), likuiditas (CR), nilai perusahaan (PBV), terhadap nilai perusahaan (PBV). Substruktur 2 ini memiliki persamaan sebagai berikut:

$\mathrm{Y}=\alpha+\beta 4 \mathrm{X} 1+\beta 5 \mathrm{X} 2+\beta 6 \mathrm{X} 3+\beta 7 \mathrm{Z}$ Rangkuman hasil perhitungan regresi untuk persamaan substruktur 2 diberikan pada tabel 3.

Berdasarkan hasil rangkuman diperoleh model regresi sebagai berikut:

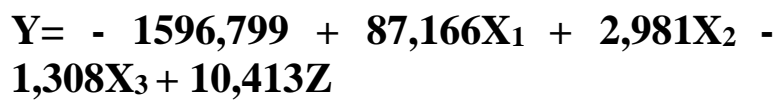


Tabel 3. Regresi X1, X2, X3, Z Terhadap Y

\begin{tabular}{|c|c|c|c|c|c|}
\hline Variabel & $\begin{array}{c}\text { Unstandardized } \\
(\mathbf{B})\end{array}$ & $\begin{array}{c}\text { Standardized } \\
(\text { Beta) }\end{array}$ & $\begin{array}{c}\text { Std. } \\
\text { Error }\end{array}$ & $\begin{array}{c}\mathbf{t} \\
\text { hitung }\end{array}$ & Sig. \\
\hline $\mathrm{X} 1$ & 87,166 & 0,801 & 6,606 & 13,194 & 0,000 \\
\hline $\mathrm{X} 2$ & 2,981 & 0,266 & 0,867 & 3,438 & 0,001 \\
\hline $\mathrm{X} 3$ & $-1,308$ & $-0,095$ & 0,923 & $-1,417$ & 0,161 \\
\hline $\mathrm{Z}$ & 10,413 & 0,101 & 7,301 & 1,426 & 0,159 \\
\hline Konstanta & $-1596,799$ & & \\
\hline Fhitung;Sig & 53,$559 ; 0,000$ & \multicolumn{5}{|l}{} \\
\hline Adjusted R R $^{2}$ & 0,753 &
\end{tabular}

Sumber: Data Sekunder Olah (2018)

\section{Koefisien Determinasi (Adjusted R $\mathbf{2}^{\mathbf{2}}$}

Nilai koefisien determinasi pada model substruktur 2 yaitu 0,767 , sehingga dapat diartikan variabel ROA, DER, CR, dan pengungkapan sustainability report secara simultan dapat mempengaruhi nilai perusahaan sebesar $75,3 \%$ sedangkan sisanya yaitu $24,7 \%$ variabel nilai perusahaan dipengaruhi oleh variabel lainnya.

\section{Uji Simultan (Uji F)}

Berdasarkan perhitungan model substruktur 2, diperoleh nilai signifikansi untuk uji $\mathrm{F}$ yaitu 0,000 dan Fhitung 53,559 sehingga nilai signifikansi lebih kecil dari 0,05 dan dapat dikatakan bahwa variabel ROA, DER, CR, dan pengungkapan sustainability report secara simultan dapat mempengaruhi nilai perusahaan. Hal ini juga mengartikan bahwa model regresi $\mathrm{Y}=$ $1596,799+87,166 X_{1}+2,981 X_{2}-1,308 X_{3}+$ $10,413 Z$ layak digunakan.

\section{Uji t}

Untuk menguji hipotesis ROA, DER, dan CR terhadap pengungkapan SRDI dan PBV digunakan uji t. Dari hasil uji $t$ diketahui bahwa

\section{Hipotesis 1: Pengaruh Profitabilitas Terhadap Pengungkapan Sustainability Report}

Hipotesis pertama yang diajukan adalah terdapatpengaruh profitabilitas yang diproksikan oleh ROA terhadap pengungkapan sustainability report.
Pengaruhnya ditunjukkan oleh nilai koefisien regresi ROA (X1) sebesar $\beta 1=0,097$ pada model persamaan regresi linear berganda $Z=107,707+0,097 X 1-0,062 X 2-0,021 X 3$

Koefisien regresi ROA (X1) sebesar $\beta 1$ $=0,097$ memiliki nilai signifikansi probabilitas $\mathrm{t}$ hitung sebesar 0,383. Karena $\beta 1 \neq 0$ dan probabilitas t hitung lebih besar daripada taraf uji penelitian ( $\mathrm{Sig} \mathrm{t}>\alpha$ atau $0.383>0.05$ ), maka $\mathrm{H}_{1 \mathrm{o}}$ diterima dan $\mathrm{H}_{1 \mathrm{a}}$ ditolak, artinya tidak terdapat pengaruh yang signifikan dari ROA terhadap pengungkapan sustainability report.

\section{Hipotesis 2: Pengaruh Solvabilitas Terhadap Pengungkapan Sustainability Report}

Hipotesis kedua yang diajukan adalah terdapat pengaruh solvabilitas yang diproksikan oleh DERterhadap pengungkapan sustainability report. Pengaruhnya ditunjukkan oleh nilai koefisien regresi DER (X2) sebesar $\beta 2=-0,062$ pada model persamaan regresi linear berganda $Z=107,707+0,097 X 1-0,062 X 2-0,021 X 3$.

Koefisien regresi DER (X2) sebesar $\beta 2$ $=-0,062$ memiliki nilai signifikansi probabilitas $\mathrm{t}$ hitung sebesar 0,000 . Karena $\beta 2 \neq 0$ dan probabilitas t hitung lebih kecil daripada taraf uji penelitian (Sig $\mathrm{t}<\alpha$ atau $0,000<0.05$ ), maka $\mathrm{H}_{2 o}$ ditolak dan $\mathrm{H}_{2 \mathrm{a}}$ diterima, artinya terdapat pengaruh yang signifikan dari DER terhadap pengungkapan sustainability report. Nilai koefisien regresi yaitu -0,062 dapat diartikan adanya pengaruh yang negatif dari DER terhadap pengungkapan sustainability report artinya 
semakin tinggi DER maka pengungkapan sustainability report akan semakin rendah.

\section{Hipotesis 3: Pengaruh Likuiditas Terhadap Pengungkapan Sustainability Report}

Hipotesis ketiga yang diajukan adalah terdapat pengaruh likuiditas yang diproksikan oleh CR terhadap pengungkapan sustainability report. Pengaruhnya ditunjukkan oleh nilai koefisien regresi $\mathrm{CR}$ (X3) sebesar $\beta 3=-0,021$ pada model persamaan regresi linear berganda $Z=107,707+0,097 X 1-0,062 X 2-0,021 X 3$

Koefisien regresi CR (X3) sebesar $\beta 3=$ $-0,021$ memiliki nilai signifikansi probabilitas $t$ hitung sebesar 0,182. Karena $\beta 3 \neq 0$ dan probabilitas t hitung lebih besar daripada taraf uji penelitian (Sig $\mathrm{t}>\alpha$ atau 0,182> 0.05), maka $\mathrm{H}_{30}$ diterima dan $\mathrm{H}_{3 a}$ ditolak, artinya tidak terdapat pengaruh yang signifikan dari $\mathrm{CR}$ terhadap pengungkapan sustainability report.

\section{Hipotesis 4: Pengaruh Profitabilitas Terhadap Nilai Perusahaan}

Hipotesis keempat yang diajukan adalah terdapat pengaruh profitabilitas yang diproksikan oleh ROA terhadap nilai perusahaan. Pengaruhnya ditunjukkan oleh nilai koefisien regresi ROA (X1) sebesar $\beta 4$ $=87,166$ pada model persamaan regresi linear berganda

$$
\begin{aligned}
\mathrm{Y}= & -1596,799+87,166 \mathrm{X} 1+2,981 \mathrm{X} 2- \\
& 1,308 \mathrm{X} 3+10,413 \mathrm{Z} .
\end{aligned}
$$

Koefisien regresi ROA (X1) sebesar $\beta 4$ $=87,166$ memiliki nilai signifikansi probabilitas $t$ hitung sebesar 0,000. Karena $\beta 4 \neq 0$ dan probabilitas $t$ hitung lebih kecil daripada taraf uji penelitian (Sig $\mathrm{t}<\alpha$ atau $0,000<0.05$ ), maka $\mathrm{H}_{40}$ ditolak dan $\mathrm{H}_{4 a}$ diterima, artinya terdapat pengaruh yang signifikan dari ROA terhadap nilai perusahaan. Nilai koefisien regresi yaitu 87,166 dapat diartikan adanya pengaruh yang positif dari ROA terhadap nilai perusahaan, artinya semakin tinggi ROA maka nilai perusahaan juga akan semakin tinggi.

\section{Hipotesis 5: Pengaruh Solvabilitas Terhadap Nilai Perusahaan}

Hipotesis kelima yang diajukan adalah terdapat pengaruh solvabilitas yang diproksikan oleh DER terhadap nilai perusahaan. Pengaruhnya ditunjukkan oleh nilai koefisien regresi DER (X2) sebesar $\beta 5$ $=2,981$ pada model persamaan regresi linear berganda $\mathrm{Y}=-1596,799+87,166 \mathrm{X} 1+$ 2,981X2 - 1,308X3 + 10,413Z .

Koefisien regresi DER (X2) sebesar $\beta 5=2,981$ memiliki nilai signifikansi probabilitas t hitung sebesar 0,001 .Karena $\beta 5$ $\neq 0$ dan probabilitas $\mathrm{t}$ hitung lebih kecil daripada taraf uji penelitian (Sig $\mathrm{t}<\alpha$ atau $0,001<0.05)$, maka $\mathrm{H}_{50}$ ditolak dan $\mathrm{H}_{5 a}$ diterima,artinya terdapatpengaruh yang signifikan dari DER terhadap nilai perusahaan. Nilai koefisien regresi yaitu 2,981 dapat diartikan adanya pengaruh yang positif dari DER terhadap nilai perusahaan, artinya semakin tinggi DER maka nilai perusahaan juga akan semakin tinggi.

\section{Hipotesis 6: Pengaruh Likuiditas \\ Terhadap Nilai Perusahaan}

Hipotesis keenam yang diajukan adalah terdapat pengaruh likuiditas yang diproksikan oleh CR terhadap nilai perusahaan. Pengaruhnya ditunjukkan oleh nilai koefisien regresi CR (X3) sebesar $\beta 6=$ 1,308 pada model persamaan regresi linear berganda $Y=-1596,799+87,166 X 1+$ 2,981X2 - 1,308X3 + 10,413Z .

Koefisien regresi CR (X3) sebesar $\beta 6$ $=-1,308$ memiliki nilai signifikansi probabilitas $t$ hitung sebesar 0,161. Karena $\beta 6 \neq 0$ dan probabilitas $t$ hitung lebih besar daripada taraf uji penelitian ( $\operatorname{Sig} \mathrm{t}>\alpha$ atau 0,161> 0.05), maka $\mathrm{H}_{60}$ diterima dan $\mathrm{H}_{6 \mathrm{a}}$ ditolak, artinya tidak terdapat pengaruh yang signifikan dari CR terhadap nilai perusahaan.

\section{Hipotesis 7: Pengaruh Pengungkapan Sustainability Report Terhadap Nilai Perusahaan}

Hipotesis ketujuh yang diajukan adalah terdapat pengaruh pengungkapan sustainability report yang diproksikan oleh SRDI terhadap nilai perusahaan. 
Pengaruhnya ditunjukkan oleh nilai koefisien regresi SRDI (X4) sebesar $\beta 7=10,413$ pada model persamaan regresi linear berganda $\mathrm{Y}=$ $-1596,799+87,166 X 1+2,981 X 2-1,308 X 3$ $+10,413 Z$.

Koefisien regresi SRDI (X4) sebesar $\beta 7=10,413$ memiliki nilai signifikansi probabilitas t hitung sebesar 0,159 . Karena $\beta 6 \neq 0$ dan probabilitas $t$ hitung lebih besar daripada taraf uji penelitian (Sig t $>\alpha$ atau $0,159>0.05$ ), maka H1o diterima dan H1a ditolak, artinya tidak terdapat pengaruh yang signifikan dari pengungkapan sustainability report terhadap nilai perusahaan.

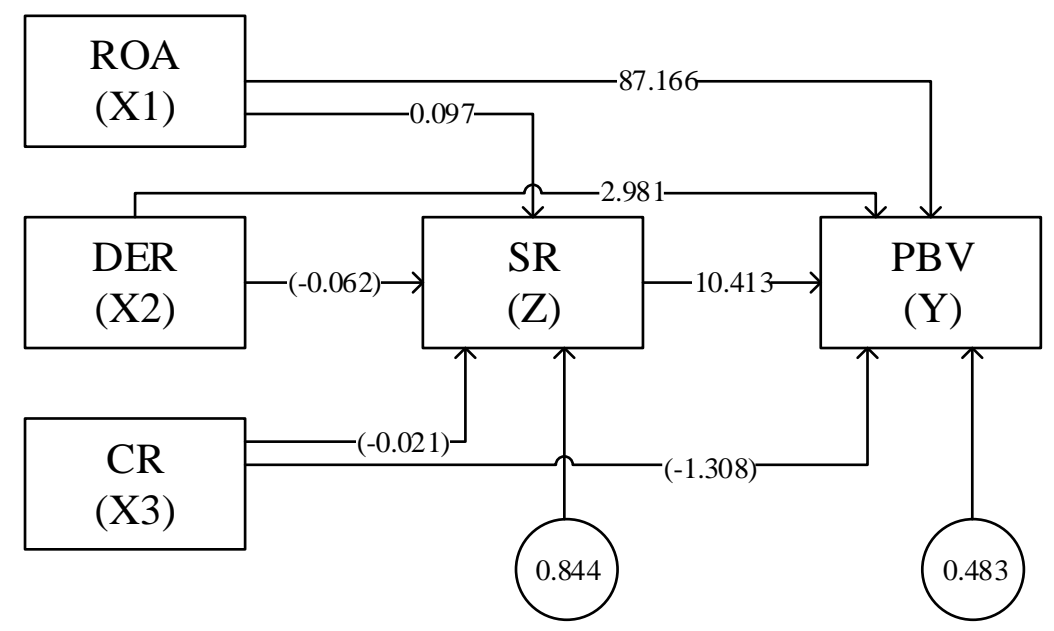

Gambar 2. Pengaruh Langsung ROA, DER, CR, dan SRDI terhadap PBV Sumber: Data Sekunder Olah (2018)

Hipotesis 8: Pengaruh Profitabilitas, Solvabilitas, dan Likuiditas Terhadap Nilai Perusahaan melalui Pengungkapan Sustainability Report

Penelitian ini menggunakan uji Sobel untuk mengetahui pengaruh tidak langsung profitabilitas, solvabilitas, likuiditas terhadap nilai perusahaan melalui pengungkapan sustainability report.

Dengan bantuan kalkulator statistik (https://www.easycalculation.com) untuk mengetahui nilai z-hitung dan tingkat signifikansi dari uji Sobel, dapat dilihat bahwa nilai z-hitung lebih kecil dari 1,96 $(0,101<1,96)$ dan tingkat signifikansi lebih besar dari $0,05(0,919>0,05)$. Hal ini berarti hasil uji Sobel z-hitung tidak memenuhi persyaratan. Dengan demikian $\mathrm{H}_{80}$ diterima dan $\mathrm{H}_{8 \mathrm{a}}$ ditolak, artinya tidak terdapat pengaruh tidak langsung yang signifikan dari profitabilitas, solvabilitas, dan likuiditas terhadap nilai perusahaan melalui pengungkapan sustainability report.
Interpretasi Hasil dan Pembahasan

Pengaruh profitabilitas (ROA) terhadap pengungkapan sustainability report (SRDI)

Nilai signifikansi pada variabel ROA terhadap pengungkapan sustainability report adalah 0,383, sehingga nilai signifikansi lebih besar dari 0,05. Oleh karena itu dapat diambil kesimpulan bahwa pada tingkat kepercayaan 95\% tidak terdapat pengaruh yang signifikan dari ROA terhadap pengungkapan sustainability report.

Hasil penelitian yang dilakukan Epstein \& Freedman (1994), menunjukkan bahwa keputusan investasi yang hanya berdasarkan informasi ekonomi sudah kurang relevan lagi. Perkembangan zaman menuntut perusahaan untuk mempertimbangkan aspek non keuangan untuk mencapai tujuan. Menurut Tomo (2011), ada keterkaitan antara profitabilitas perusahaan dengan kesadaran perusahaan meningkatkan citra perusahaan melalui kegiatan non keuangan, seperti pengungkapan laporan keberlanjutan perusahaan. Namun hasil penelitian ini 
menunjukkan hasil berbeda dari penelitian Tomo tersebut.

\section{Pengaruh Solvabilitas (DER) terhadap Pengungkapan Sustainability Report (SRDI)}

Nilai signifikansi pada variabel DER terhadap pengungkapan sustainability report adalah 0,000 , sehingga nilai signifikansi lebih kecil dari 0,05. Oleh karena itu dapat diambil kesimpulan bahwa pada tingkat kepercayaan 95\% terdapat pengaruh yang signifikan dari DER terhadap pengungkapan sustainability report. Nilai koefisien regresi yaitu -0,062 dapat diartikan adanya pengaruh yang negatif dari DER terhadap pengungkapan sustainability report. Artinya semakin tinggi solvabilitas maka pengungkapan sustainability report akan semakin rendah. Nilai koefisien regresi ini juga menunjukkan adanya penurunan pengungkapan sustainability report sebesar 0,062 satuan setiap kenaikan satu-satuan dari DER.

Hartono (2005) mengungkapkan bahwa sinyal dari manajemen perusahaan kepada investor mempengaruhi keputusan investasi. Solvabilitas sebagai sebuah rasio keuangan memberikan sinyal kepada investor mengenai cara perusahaan memaksimalkan kekayaan pemilik sesuai tujuan perusahaan. Sehingga semakin baik rasio solvabilitas maka semakin tinggi nilai perusahaan. Penelitian mengenai pengaruh solvabilitasterhadap pengungkapan sustainability report pernah dilakukan oleh Aniktia and Khafid (2015) yang menyimpulkan bahwa ada pengaruh positif signifikan antara solvabilitas terhadap pengungkapan sustainability report. Oleh karena itu, hasil penelitian ini tidak sejalan dengan penelitian yang telah dilakukan oleh Aniktia and Khafid (2015) tersebut.

\section{Pengaruhlikuiditas (CR) terhadap Pengungkapan Sustainability Report (SRDI)}

Nilai signifikansi pada variabel CR terhadap pengungkapan sustainability report adalah 0,182 , sehingga nilai signifikansi lebih besar dari 0,05. Oleh karena itu dapat diambil kesimpulan bahwa pada tingkat kepercayaan $95 \%$ tidak terdapat pengaruh yang signifikan dari CR terhadap pengungkapan sustainability report.

Munawir (2014) menyebutkan bahwa likuiditas adalah suatu indikator mengenai kemampuan perusahaan untuk membayar semua kewajiban finansial jangka pendek pada saat jatuh tempo dengan menggunakan aktiva lancar yang tersedia. Adanya keterbukaan informasi tentang likuiditas perusahaan, maka ada itikad baik dari manajemen perusahaan untuk terus tumbuh berkembang dan terus berkelanjutan usahanya. Prinsip ini sama dengan prinsip dasar pengungkapan sustainability report yang tidak hanya melaporkan aspek keuangan namun juga aspek keberlanjutan. Penelitian ini tidak sejalan dengan hasil penelitian mengenai pengungkapan sustainability report yang pernah dilakukan oleh Saputro, et al (2013) yang menyimpulkan bahwa terdapat pengaruh positif signifikan antara likuiditas terhadap pengungkapan sustainability report.

\section{Pengaruh Profitabilitas (ROA) terhadap Pilai Perusahaan (PBV)}

Nilai signifikansi pada variabel ROA terhadap nilai perusahaan adalah 0,000, sehingga nilai signifikansi lebih kecil dari 0,05. Oleh karena itu dapat diambil kesimpulan bahwa pada tingkat kepercayaan 95\% terdapat pengaruh yang signifikan dari ROA terhadap nilai perusahaan. Nilai koefisien regresi yaitu 87,166 dapat diartikan adanya pengaruh yang positif dari ROA terhadap nilai perusahaan. Artinya semakin tinggi profitabilitas maka nilai perusahaan juga akan semakin tinggi. Nilai koefisien regresi ini juga menunjukkan adanya kenaikan nilai perusahaan sebesar 87,166 satuan setiap kenaikan satu-satuan dari ROA.

Profitabilitas adalah salah satu analisis terpenting untuk mengukur kemampuan perusahaan untuk menghasilkan laba (Sudana, 2011). Semakin tinggi profitabilitas maka semakin besar return yang diperoleh oleh investor, sehingga nilai perusahaan 
menjadi semakin meningkat. Hasil penelitian terbaru yang mengukur pengaruh profitabilitas terhadap nilai perusahaan juga memberikan hasil signifikan positif, diantaranya penelitian yang dilakukan oleh Alamsyah (2017), Dhani \& Utama (2017), Ayu \& Suarjaya (2017), Hamidah \& Umdiana (2017), serta Suwardika \& Mustanda (2017). Hasil penelitian ini menunjukkan bahwa semakin tinggi profitabilitas maka akan semakin tinggi pula nilai perusahaan.

\section{Pengaruh solvabilitas (DER) terhadap nilai perusahaan (PBV)}

Nilai signifikansi pada variabel DER terhadap nilai perusahaan adalah 0,001, sehingga nilai signifikansi lebih kecil dari 0,05. Oleh karena itu dapat diambil kesimpulan bahwa pada tingkat kepercayaan 95\% terdapat pengaruh yang signifikan dari DER terhadap nilai perusahaan. Nilai koefisien regresi yaitu 2,981 dapat diartikan adanya pengaruh yang positif dari DER terhadap nilai perusahaan. Hal ini berarti semakin tinggi solvabilitas maka nilai perusahaan juga akan semakin tinggi. Nilai koefisien regresi ini juga menunjukkan adanya kenaikan nilai perusahaan sebesar 2,981 satuan setiap kenaikan satu-satuan dari DER.

Solvabilitas adalah rasio yang mengukur seberapa besar perusahaan menggunakan pendanaan dari hutang. Perusahaan cenderung menggunakan hutang untuk kegiatan operasionalnya sehingga mampu memberikan return kepada investor (Brigham \& Houston, 2001). Dengan hutang, maka laba ditahan bisa dikurangi semaksimal mungkin dan bisa dibagi secara maksimal kepada investor. Hal inilah yang memberikan sinyal positif kepada investor bahwa sebuah perusahaan memberikan keuntungan dengan lebih banyaknya return yang dibagi. Dengan demikian, semakin tinggi rasio solvabilitas maka semakin tinggi pula nilai perusahaan. Hal ini didukung oleh hasil penelitian yang dilakukan oleh Aditya \& Naomi (2017), Suwardika \& Mustanda (2017), serta Pratama \& Wirawati (2016) yang memberikan

hasil

bahwa

solvabilitasberpengaruh positif signifikan terhadap nilai perusahaan tetapi berbeda dengan hasil penelitian Widhiastuti dkk (2018), hasil penelitianya menunjukkan bahwa DER berpengaruh negatif terhadap nilai perusahaan.

\section{Pengaruh likuiditas (CR) terhadap nilai perusahaan (PBV)}

Nilai signifikansi pada variabel CR terhadap nilai perusahaan adalah 0,161 , sehingga nilai signifikansi lebih besar dari 0,05 . Oleh karena itu dapat diambil kesimpulan bahwa pada tingkat kepercayaan 95\% tidak terdapat pegaruh yang signifikan dari CR terhadap nilai perusahaan.

Likuiditas adalah suatu rasio mengenai kemampuan perusahaan untuk membayar semua kewajiban finansial jangka pendek pada saat jatuh tempo dengan menggunakan aktiva lancar yang tersedia. Menurut Munawir (2014), rasio likuiditas menunjukkan kesehatan dari perusahaan yang bisa dianalisis oleh para investor. Semakin tinggi rasio likuiditas maka perusahaan tersebut akan dipandang sebagai perusahaan yang prospektif, yang tentu saja menaikkan nilai perusahaan. Hasil penelitian ini tidak sejalan dengan penelitian yang telah dilakukan oleh beberapa hasil penelitian terdahulu yang dilakukan oleh Jantana (2017) dan Jariah (2016). Namun demikian hasil penelitian ini sejalan dengan hasil penelitian Nugroho (2012), Firnanda \& Oetomo (2016), dan Mahendra (2012) yang menyatakan bahwa likuiditas tidak berpengaruh signifikan terhadap nilai perusahaan.

\section{Pengaruh Pengungkapan Sustainability Report (SRDI) terhadap Nilai Perusahaan (PBV)}

Nilai signifikansi pada variabel pengungkapan sustainability report terhadap nilai perusahaan adalah 0,159 , sehingga nilai signifikansi lebih besar dari 0,05. Oleh karena itu dapat diambil kesimpulan bahwa pada tingkat kepercayaan $95 \%$ tidak terdapat pegaruh yang signifikan dari pengungkapan 
sustainability report terhadap nilai perusahaan.

Berdasarkan pemaparan sebelumnya mengenai nilai perusahaan, sejak tahun 2009 nilai pasar perusahaan ditentukan hanya $19 \%$ oleh aspek keuangan dan sisanya $81 \%$ oleh aspek nonkeuangan (Tomo, 2011). Salah satu isu dari aspek non keuangan adalah aspek keberlanjutan (sustainability). Elkington (1997) mengatakan bahwa pengungkapan sustainability report tidak hanya memuat informasi mengenai kinerja keuangan saja, tetapi juga informasi non keuangan yang terdiri dari informasi aktivitas sosial dan lingkungan yang memungkinkan perusahaan bisa bertumbuh secara berkesinambungan. Dari dasar teori tersebut dapat disimpulkan bahwa pengungkapan sustainability report akan meningkatkan nilai perusahaan. Hasil penelitian ini tidak sejalan dengan hasil penelitian yang dilakukan oleh Safitri (2015) yang menyimpulkan bahwa pengungkapan sustainability report berpengaruh positif signifikan terhadap nilai perusahaan.

\section{Pengaruh Profitabilitas (ROA), Solvabilitas (DER), dan Likuiditas (CR) terhadap Nilai Perusahaan (PBV) yang Dimediasi oleh Pengungkapan Sustainability Report (SRDI)}

Profitabilitas, solvabilitas, dan likuiditas tidak memiliki pengaruh terhadap nilai perusahaan yang dimediasi oleh pengungkapan sustainability report. Hal ini dibuktikan dengan nilai signifikansi pada pengaruh profitabilitas, solvabilitas, dan likuiditas terhadap nilai perusahaan melalui pengungkapan sustainability report dengan uji Sobel yaitu signifikansi 0,919 sehingga nilai signifikansi lebih besar dari 0,05 dan nilai z-hitung dari uji Sobel yaitu 0,101 sehingga nilai z lebih kecil dari 1,96.

Hasil penelitian ini tidak sejalan dengan teori dari Elkington (1997) dan survey dari Accenture (2013) yang menggambarkan bahwa dunia usaha saat ini sedang berubah dan memiliki kesadaran baru bahwa tujuan perusahaan tidak semata-mata profit, namun juga keberlanjutan. Tujuan keberlanjutan (sustainability) pada ujungnya adalah untuk meningkatkan nilai perusahaan.

\section{KESIMPULAN \\ Kesimpulan}

Berdasarkan hasil penelitian mengenai nilai perusahaan pada perusahaan-perusahaan yang masuk dalam index SRI-KEHATI pada periode 2012 sampai 2016, dapat diberikan kesimpulan sebagai berikut:

(1) Tidak terdapat pegaruh yang signifikan dari profitabilitas terhadap pengungkapan sustainability report. Artinya, tinggi rendahnya profitabilitas tidak menentukan pengungkapan sustainability report akan naik atau turun.

(2) Terdapat pengaruh negative yang signifikan dari solvabilitas terhadap pengungkapan sustainability report. Dengan adanya pengaruh negatif dari solvabilitasterhadap pengungkapan sustainability report, berarti semakin tinggi solvabilitas maka pengungkapan sustainability report akan semakin rendah.

(3) Tidak terdapat pegaruh yang signifikan dari likuiditas terhadap pengungkapan sustainability report. Artinya, tinggi rendahnya likuiditas tidak menentukan pengungkapan sustainability report akan naik atau turun.

(4) Terdapat pegaruh positif yang signifikan dari profitabilitas terhadap nilai perusahaan. Dengan adanya pengaruh yang positif dari profitabilitas terhadap nilai perusahaan, berarti semakin tinggi profitabilitas maka nilai perusahaan juga akan semakin tinggi.

(5) Terdapat pegaruh yang signifikan dari solvabilitas terhadap nilai perusahaan. Dengan adanya pengaruh yang positif dari solvabilitas terhadap nilai perusahaan, berarti semakin tinggi solvabilitas maka nilai perusahaan juga akan semakin tinggi.

(6) Tidak terdapat pengaruh yang signifikan dari likuiditas terhadap nilai perusahaan. Artinya, tinggi rendahnya likuiditas tidak menentukan nilai perusahaan akan naik 
atau turun. (7) Tidak terdapat pegaruh yang signifikan dari pengungkapan sustainability report terhadap nilai perusahaan. Artinya, tinggi rendahnya pengungkapan sustainability report tidak menentukan nilai perusahaan akan naik atau turun.

(7) Profitabilitas, solvabilitas, dan likuiditas tidak memiliki pengaruh terhadap nilai perusahaan yang dimediasi oleh pengungkapan sustainability report. Artinya, variabel pengungkapan sustainability report tidak dapat menjadi variabel mediasi pada pengaruh profitabilitas, solvabilitas, dan likuiditas terhadap nilai perusahaan.

\section{Saran}

Berdasarkan hasil penelitian mengenai nilai perusahaan pada perusahaan-perusahaan yang masuk dalam index SRI-KEHATI pada periode 2012 sampai 2016, dapat diberikan saran sebagai berikut:

(1) Bagi investor dapat menggunakan hasil penelitian mengenai faktor-faktor yang menentukan nilai perusahaan ini untuk mengambil keputusan terkait invesati.

(2) Salah satu variabel dependen yang digunakan dalam penelitian ini adalah pengungkapan sustainability report. Namun dari hasil uji determinasi hanya didapatkan $25,6 \%$, yang berarti ada 74,4 $\%$ variabel lain yang berpengaruh terhadap sustainability report. Untuk itu jika peneliti selanjutnya ingin mengungkapan faktor-faktor yang mempengaruhi pengungkapan sustainability report, perlu ditambahkan faktor-faktor lain.

\section{REFERENSI}

Accenture. 2013. The UN Global CompactAccenture CEO Study on Sustainability: Architects of a Better World. UN Global Compact Reports. Dublin: Accenture Sustainability.

Aditya, Oka, and Prima Naomi. 2017. "Penerapan Manajemen Risiko Perusahaan dan Nilai Perusahaan di Sektor Konstruksi dan Properti." Jurnal Bisnis dan Manajemen 7 (2): 167-180.
Alamsyah, Sustari. 2017. "Pengaruh Profitabilitas Terhadap Nilai Perusahaan, Relevansi Nilai Informasi Akuntansi, Keputusan Investasi, Kebijakan Dividen Sebagai Variabel Intervening." Jurnal Akutansi dan Keuangan Competitive 1 (1).

Aniktia, Ria, and Muhammad Khafid. 2015. "Pengaruh Mekanisme Good Corporate Governance dan Kinerja Keuangan Terhadap Pengungkapan Sustainability Report." Accounting Analysis Journal 4 (3).

Astuti, Apri Dwi, and Juwenah. 2017. "Pengaruh Pengungkapan Sustainibility Report Terhadap Nilai Perusahaan Yang Tergabung Dalam LQ 45 tahun 2012-2013." Jurnal Unsika Karawang 1 (1). www.unsika.ac.id.

Ayu, Dea Putri, and Gede Suarjaya. 2017. "Pengaruh Profitabilitas Terhadap Nilai Perusahaan Dengan Corporate Sosial Responsibility Sebagai Variabel Mediasi Pada Perusahaan Pertambangan." E-Jurnal Manajemen Unud 6 (2): 1112-1138.

Brigham, Eugene, and Joel F. Houston. 2001. Manajemen Keuangan II. 1 st. Translated by Dodo Suharto. Jakarta: Erlangga.

Carningsih. 2012. "Pengaruh Good Corporate Governance terhadap Hubungan antara Kinerja Keuangan dengan Nilai Perusahaan." Jurnal Dinamika Manajemen 1 (3): 20-28.

Chariri, Anis, and Firman Aji Nugroho. 2009. "Retorika dalam Pelaporan Corporate Sosial Responsibility: Analisis Semiotik atas Sustainability Reporting PT Aneka Tambang Tbk." Simposium Nasional Akuntansi XII . Palembang.

Dhani, Isabella Permata, and AA. Gde Satia Utama. 2017. "Pengaruh Pertumbuhan Perusahaan, Struktur Modal, dan Profitabilitas Terhadap Nilai Perusahaan." Jurnal Riset Akuntansi dan Bisnis Airlangga 2 (1): 135-148. 
Effendi, Muhammad Arief. 2009. The Power of Good Corporate Governance Teori dan Aplikasi. Jakarta: Salemba Empat.

Elkington, John. 1997. Cannibals with Forks: The Triple Bottom Line of 21st Century Business. Oxford: Capstone Publishing Ltd.

Epstein, Marc. J., and Martin Freedman. 1994. "Sosial Disclosure and The Individual Investor." Accounting, Auditing, \& Accountability Journal 4 (7): 94-109.

Fahmi, Irham. 2011. Analisis Laporan Keuangan. Bandung: Alfabeta.

Firnanda, Taurisina, and Hening Widi Oetomo. 2016. "Analisis Likuiditas, Profitabilitas, Solvabilitas, Dan Perputaran Persediaan Terhadap Nilai Perusahaan." Jurnal Ilmu dan Riset Manajemen 5 (2).

Ghozali, Imam. 2011. Aplikasi Analisis Multivariate Dengan Program SPSS. Semarang: Badan Penerbit Universitas Diponegoro.

Global Strategic Alliances. 2017. Global Reporting Index. https://www.globalreporting.org/standa rds.

Hamidah, Ghina, dan Nana Umdiana. 2017. "Pengaruh Profitabilitas Dan Investment Opportunity Set (Ios) Terhadap Nilai Perusahaan Dengan Harga Saham Sebagai Variabel Intervening." Jurnal Akuntansi (Universitas Serang Raya) 3 (2).

Harahap, Sofyan Safri. 2013. Analisis Kritis atas Laporan Keuangan. Jakarta: Raja Grafindo Persada.

Hartono, Jogiyanto . 2005. Analisis dan Desain Sistem Informasi: Pendekatan Terstruktur Teori dan Praktis Aplikasi Bisnis. Yogyakarta: Andi Offset.

Hermawan, Sigit , and Afiyah Nurul Maf'ulah. 2014. "Pengaruh Kinerja Keuangan Terhadap Nilai Perusahaan Dengan Pengungkapan CSR Sebagai Variabel Pemoderasi." Jurnal
Dinamika Akutansi (Unnes) 6 (2): 103-118.

Jama'an. 2008. "Pengaruh Mekanisme Corporate Governance dan Kualitas Kantor Akuntan Publik Terhadap Integritas Informasi Laporan Keuangan." Tesis Pada Studi Magister Sains Akuntansi, Universitas Diponegoro.

Jantana, Indra. 2017. "Pengaruh Struktur Modal, Profitabilitas, Dan Likuiditas Terhadap Nilai Perusahaan Pada Perusahaan Sektor Barang Konsumsi Sub-Sektor Rokok Di BEI Tahun 2007-2011." Skripsi pada Fakultas Ekonomi Universitas Lampung.

Jariah, Ainun. 2016. "Likuiditas, Leverage, Profitabilitas Pengaruhnya Terhadap Nilai Perusahaan Manufaktur Di Indonesia Melalui Kebijakan Deviden." Riset Akuntansi dan Keuangan Indonesia 1 (2): 108-118.

Kasmir. 2008. Analisis Laporan Keuangan. Jakarta: Rajawali Pers

Kramer, Mark R., and Michael E. Porter. 2006. "Strategy and Society: The Link between Competitive Advantage and Corporate Sosial Responsibility." Harvard Business Review 84 (12): 78-92.

Lybryanta, Ocktav Andrian, Akhmad Toha, and Ika Sisbintari. 2015. "Pengaruh Kinerja Keuangan terhadap Nilai Perusahaan di Perusahaan Makanan dan Minuman." E-SOSPOL Universitas Jember 2 (1): 7 - 11.

Mahendra Dj, Alfredo, Luh Gede Sri Artini, and AA Gede Suarjaya. 2012. "Pengaruh Kinerja Keuangan Terhadap Nilai Perusahaan Pada Perusahaan Manufaktur Di Bursa Efek Indonesia." Jurnal Manajemen, Strategi Bisnis, dan Kewirausahaan (Fakultas Ekonomi Universitas Udayana) 6 (2): 128-135.

Meidiawati, Karina, and Titik Mildawati. 2016. "Pengaruh Size, Growth, Profitabilitas, Struktur Modal, Kebijakan Dividen Terhadap Nilai 
Perusahaan." Jurnal Ilmu dan Riset 5 (2).

Mulyanto, Heru, and Ana Wulandari. n.d. Penelitian: Metode dan Analisis. Semarang: CV. Agung.

Munawir, Drs. S. 2014. Analisa Laporan Keuangan (Edisi 4). Yogyakarta: Liberty.

NCSR. 2017. http://www.ncsr-id.org. http://www.ncsr-id.org.

Nugroho, Wahyudi Asto. 2012. "Pengaruh Profitabilitas, Likuiditas, dan Leverage Terhadap Nilai Perusahaan." Tesis pada Program Pascasarjana Universitas Muhammadiyah Surakarta.

Nurlela, and Islahuddin. 2008. "Pengaruh Corporate Sosial Responsibility terhadap Nilai Peusahaan dengan Prosentase Kepemilikan Manajemen sebagai Variabel Moderating." Simposium Nasional Akuntansi XI.

Pratama, I Gede Gora Wira, and Ni Gusti Putu Wirawati. 2016. "Pengaruh Struktur Modal Dan Profitabilitas Terhadap Nilai Perusahaan Dengan Kepemilikan Manajerial Sebagai Pemoderasi." E-Jurnal Akuntansi Universitas Udayana 15 (3): 1796-1825.

Pratiwi, Ririh Dian, and Anna Sumaryati. 2014. "Dampak Sustainability Report Terhadap Kinerja Keuangan dan Resiko Perusahaan." Jurnal Dinamika Akutansi 6 (12).

Ramadhani, Ieman Aji. 2016. "Pengaruh Pengungkapan Sustainibility Report Terhadap Nilai Perusahaan dengan Profitabilitas Sebagai Moderasi." Jurnal Ilmiah Mahasiswa Fakultas Ekonomi dan Bisnis Universitas Brawijaya 4 (2).

Riyanto, Bambang. 2001. Dasar-dasar pembelanjaan Perusahaan. Yogyakarta: BPFE.

Safitri, Dian Anggraeni. 2015. "Sustainibility Report Terhadap Kinerja Keuangan dan Pasar." Jurnal Ilmu dan Riset Akutansi 4 (4).
Saputro, Dwi Anggoro, Fachrurrozi, and Linda Agustina. 2013. "Pengaruh Kinerja Keuangan Terhadap Pengungkapan Sustainaibility Report." Accounting Analysis Journal 2 (4).

Sartono, Agus. 2010. Manajemen Keuangan Teori dan Aplikasi. Yogyakarta: BPFE.

Schacter, Daniel, Daniel T Gilbert, Daniel M. Wagner, and Mattew K. Nock. 2011. Psychology. Worth Publishers.

Sobel , Michael E. 1982. "Asymptotic Confidence Intervals for Indirect Effects in Structural Equation Models." Sociological Methodology (John Wiley \& Sons) 13: 290-312. doi:10.2307/270723.

Sudana, I Made. 2011. Manajemen Keuangan Perusahaan. Jakarta: Erlangga.

Suffah, Roviqotus, and Akhmad Riduwan. 2016. "Pengaruh Profitabilitas, Leverage, Ukuran Perusahaan Dan Kebijakan Dividen Pada Nilai Perusahaan." Jurnal Ilmu dan Riset Akuntansi 5 (2).

Sujoko, and Ugy Soebiantoro. 2007. "Pengaruh Struktur Kepemilikan Saham, Leverage, Faktor Intern dan Faktor Ekstern terhadap Nilai Perusahaan." Jurnal Manajemen dan Kewirausahaan 9 (1): 41-48.

Suwardika, I Nyoman Agus, and I Ketut Mustanda. 2017. "Pengaruh Leverage, Ukuran Perusahaan, Pertumbuhan Perusahaan, Dan Profitabilitas Terhadap Nilai Perusahaan Pada Perusahaan Properti." E-Jurnal Manajemen Unud 6 (3): 1248-1277.

Tomo, Ocean;. 2011. Annual Study of Intangible Asset and Market Value. Chicago: The Intellectual Capital Merchant Bank Firm.

Van Horne, James C. , and John M. Wachowicz, Jr. 2005. Prinsip-prinsip Manajemen Keuangan (Edisi ke-12). Jakarta: Salemba Empat. 
Weber, Olaf, Thomas Koellner, Dominique Habegger, and Peter Ohnemus. 2008. "The Relation Between Sustainability Performance and Financial Performance of Firms." Progress in Industrial Ecology 236-254.

Widhiastuti,Susanti; Etty M dan Sekar M. 2018. "The Effect of Business Intelligence and Intellectuals Capital of Company Value Moderated by Management of Profit Riil" Journal of Accounting, Business and Finance Research, Vol. 2, No. 2, pp. 64-78. www.idx.co.id

Yayasan KEHATI. 2017. Index SRI KEHATI.

http://www.kehati.or.id/indeks-srikehati/. 